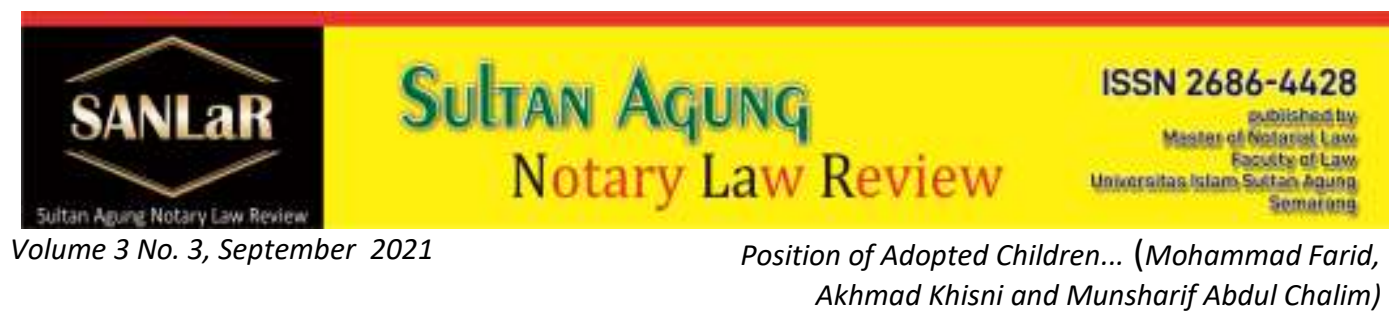

\title{
Position of Adopted Children in Leaving Appointment Parent's Assets According To Islamic Law, Civil Law \& Custom Law
}

\author{
Mohammad Farid ${ }^{*}$, Akhmad Khisni ${ }^{* *}$ and Munsharif Abdul Chalim ${ }^{* * *}$ ) \\ ${ }^{*}$ Faculty of Law, Universitas Islam Sultan Agung (UNISSULA) Semarang, E-mail: \\ mfarid2021@gmail.com \\ $\left.{ }^{* *}\right)$ Faculty of Law, Universitas Islam Sultan Agung (UNISSULA) Semarang, E-mail: \\ khisni@unissula.ac.id
}

${ }^{* * *}$ Faculty of Law, Universitas Islam Sultan Agung (UNISSULA) Semarang, E-mail:
munsharifac@gmail.com

\begin{abstract}
In Islam, adoption is known as tabann, Wahbah al-Zuhaily gives the understanding that adoption (tabann) is the taking of a child by someone to a child whose lineage is clear and then the child is assigned to him. One of the supporting factors for the realization of a household in accordance with this Islamic concept is property which is Zinatu al-Hayat, both movable and immovable property, even including securities and intellectual rights Inheritance rights that apply to adopted children to property adoptive parents in Islamic law, civil law, and customary law. Method This approach uses a secondary approach that is normative law or literature writing with a statutory approach. Indonesia adheres to a plural legal system, which means that Indonesia adheres to more than one legal system. This also makes inheritance law divided into three legal systems, namely Western Law, Islamic Law, and Customary Law. In general, the notion of inheritance law is a legal rule that regulates the transfer of property rights, which is the overall rights and obligations of the person who inherits to his heirs and determines who is entitled to receive it. Indonesia adheres to several systems of inheritance law including the civil law system, Islamic law and customary law. In civil law, adopted children still get inheritance rights from their adoptive parents. Then in customary law, the inheritance system used is dependent on the custom where the adopted child lives.
\end{abstract}

Keywords: Adopted; Children; Inheritance; Islamic; Civil; Custom; Law. 


\section{Introduction}

Marriage is a human desire for every human being, as stated in Article 1 of Act No. 1 of 1974 concerning Marriage, the purpose of marriage is to form a happy and eternal family based on the One Godhead. For most married couples, it is considered that a marriage can be said to be imperfect if the husband and wife have not been blessed with children, because basically every couple wants to have children because it means a lot in fostering a family, society and mankind. In addition, children are also entertainers who are very close to their parents and can arouse a sense of responsibility and affection. ${ }^{1}$

Therefore, it feels incomplete for a family without the presence of a child. In fact, in certain cases without the presence of a child is considered a disgrace that causes a lack of confidence for married couples, as if a marriage does not produce offspring, then the purpose of the marriage is not achieved. Then the idea of having children by adoption or adopted children arose, if a child was not present in a household. Of course, the child adopted here is someone else's child, then adopted as his own child. So legally adopted children have the same rights and obligations as biological children.

In Islam, adoption is known as tabann, Wahbah al-Zuhaily gives the understanding that adoption (tabann) is the taking of a child by someone to a child whose lineage is clear and then the child is assigned to him. In addition, tabann is a person, both male and female, who deliberately assigns a child to himself even though the child already has a clear lineage with his biological parents. Every husband and wife always crave the creation of a sakinah, mawaddah and warahmah household. One of the supporting factors for the realization of a household that is in accordance with this Islamic concept is assets which are zinatu al-hayat, both movable and immovable assets, even including securities and intellectual rights. ${ }^{2}$

Regulations governing child adoption are contained among others in the Civil Code which applies to Chinese (Chinese) citizens, namely Staatsblaad 1917 Number 129 concerning Child Adoption (adoption), Act No. 23 of 2002 concerning Child Protection in conjunction with Act No. 35 of 2014 concerning Changes Based on Act No. 23 of 2002 concerning Child Protection, Government Regulation Number 54 of 2007 concerning Implementation of Child Adoption and Presidential Instruction Number 1 of 1991 concerning the Compilation of Islamic Law (KHI). The implementation of child adoption through the courts is regulated in the Supreme Court Circular (SEMA) Number 2 of 1979 which was

\footnotetext{
${ }^{1}$ Kamus Nasional Indonesia, (1988), Jilid IA, Jakarta: PT.Cipta Adi Pusaka, p. 87

${ }^{2}$ Andi Syamsu Alam \& M. Fauzan, (2008), Hukum Pengangkatan Anak Perspektif Islam, Jakarta : Kencana, p. 20
} 
enhanced by the Supreme Court's Circular Letter (SEMA) Number 6 of 1983 concerning Child Adoption.

In general, the adoption of children is divided into two meanings, namely: first, adoption in a broad sense. This creates a kinship relationship so that there are proper rights and obligations between the children themselves and their parents. Second, is adoption in a limited sense. Namely, the adoption of other people's children into their own families and the relationship between the adopted child and the adoptive parents is limited to social relations.

Adopted children also have the right to guarantee the protection of their rights so that they are able to carry out their lives, participate optimally, and get protection from violence and/or different treatment. In fact, sometimes adopted children are still considered not part of the family which in the end, the rights of adopted children are ignored. This does not rule out the possibility of problems such as in terms of the distribution of inheritance, because they consider the adopted child is not the heir of the adopting parent.

In positive law in Indonesia, "it is known by various classifications of assets, if we look at Article 35 of Act No. 1 of 1974 concerning marriage, then marital property consists of 'joint property', 'innate property', 'gift property' and 'inheritance'. Joint assets are assets obtained by husband and wife during marriage (search assets). This joint property if the marriage breaks up (divorce or divorce) is regulated according to their respective laws (customary law, religious law or other laws). Inherited assets are assets that each husband and wife bring into the marriage bond, may be in the form of assets resulting from their own efforts, and may also be in the form of gifts or inheritance obtained by each husband and wife before or after the marriage (inherited property). ${ }^{3}$

Inheritance law is one part of civil law as a whole and is the smallest part of family law. Inheritance law is closely related to the scope of human life, because every human being will experience a legal event called death. The legal consequences that subsequently arise due to the death include the management and continuation of the rights and obligations of a person who dies.

In Indonesia itself, there are still many kinds of inheritance law, which Unification has not done because there is no one rule made by the government to unite inheritance law in Indonesia, this started since Indonesia was still colonized by the Dutch, where the main cause was the division of population groups committed by the Dutch as described in article 163 jo. 131 IS (Indische

${ }^{3}$ Hilman Hadikusuma, (2007) Hukum Perkawinan Indonesia Menurut Perundangan, Hukum Adat, Hukum Agama, Bandung : Mandar Maju, p. 114. 
Staatsregeling) which divides the population in Indonesia into three parts of legal subjects, namely:

1. The Dutch population and the Chinese group apply Dutch law;

2. The foreign eastern group applies the law of the area of origin;

3. The Bumiputera group applies their respective customary laws.

Seeing the pluralistic classification of the population described above, it can be ascertained that it is difficult to unify due to the many factors that cause it. The opinion expressed by Mochtar Kusumaatmadja regarding the inheritance process is that "the field of inheritance law is considered as one of the fields of law that is outside the 'neutral' field. Such as company law, contract law (commitment), and traffic law (land, water and air). So, according to Mochtar Kusumaatmadja's criteria, the field of inheritance law includes the field of law that contains too many obstacles, cultural, religious and sociological complications." 4

As for a brief review of the inheritance law in Indonesia, among others:

\section{Customary law}

In the distribution of inheritance according to customary law, the distribution is determined based on the existing and developing habits of the indigenous community itself, if we look at the group of heirs who will receive the inheritance, customary law broadly divides it into 3 (three) parts, namely:

a) "The principle of patrilineal lineage is a family system that counts kinship relations through men only, and therefore results in that for each individual in society all his father's relatives fall within the limits of his kinship relationship, while all his mother's relatives fall outside the boundaries of his kinship. that." ${ }^{5}$

b) "The principle of matrilineal lineage is a family system that counts kinship through women only, and therefore results in that for each individual in society all of his mother's relatives fall within the limits of his kinship, while all of his father's relatives fall outside that limit." 6

c) "The principle of parental lineage is a system that draws lineage from two sides, both the father and the mother. In this system the position of

\footnotetext{
${ }^{4}$ Mochtar Kusumaatmadja, (1976), Hukum, Masyarakat \& Pembinaan Hukum Nasional, Bandung : Bina Cipta, p.14

${ }^{5}$ Soerjono Soekanto, (2010), Hukum Adat Indonesia, Jakarta : Rajawali Pers, p.50

6 Ibid, p.51
} 
sons and daughters in inheritance law is equal and equal. ${ }^{7}$

Customary inheritance law recognizes three inheritance systems in Indonesian society, the three inheritance systems are;

1) "Individual inheritance system which is an inheritance system where the heirs inherit individually, for example: Batak, Javanese, Sulawesi

2) Collective inheritance system, where the heirs collectively (collectively) inherit inheritance that cannot be divided for ownership by each heir, for example: Minangkabau

3) Major inheritance system:

a) Male majority, i.e. if the eldest son at the time of the testator dies or the eldest son (or male descendant) is the sole heir, for example: Lampung

b) The majority of women, that is, if the eldest daughter at the time the testator dies, is the sole heir, for example: in the people of the land of semendo."

\section{Islamic law}

In Islamic law, basically the inheritance arrangement is regulated in the An-Nisa letter, namely QS Annisa: 11, 12 and 176 which in general regulates: 18

"The share of sons is equal to two daughters, two daughters or more, $2 / 3$ of the inheritance. If there is only one daughter, then she gets one-half $(1 / 2)$ of the inheritance. For the father and mother get $1 / 6$ of the inheritance. If the heir has no children then the mother gets $1 / 3$. However, if the heir has siblings but no children, the mother gets $1 / 6$. The husband gets if the wife who dies has no children, but if she has children the husband gets of the inheritance. The wife gets if the husband dies without having children, but the wife gets $1 / 8$ of the inheritance if she leaves children. If the heir dies when he dies (dead childless and fatherless), then a brother of one's mother gets $1 / 6$ of the inheritance. Meanwhile, if more than one person then gets $1 / 3$ of the inheritance. If what is left is a person who dies and has a sister, then he gets of the inheritance. If more than one sister then get $2 / 3$ of the inheritance. If there are sisters and brothers, then the share of brothers is twice that of sisters."

However, in its application, due to the many perceptions that exist in the community regarding the distribution of Islamic inheritance, three Islamic legal arrangements that can be used in the distribution of inheritance are determined, as for the arrangements, among others:

${ }^{7}$ Eman Suparman, (2005) Hukum Waris Indonesia dalam perspektif islam, adat, \& BW. Bandung : Refika Aditama, p.42 
a) The patrilineal inheritance system according to Imam Shafi'i;

b) Bilateral inheritance system according to Prof. Hazairin;

c) Inheritance system according to the Compilation of Islamic Law.

3. Civil law

Arrangements regarding the distribution of inheritance if we look at it from the point of view of western civil law are regulated in book II of the Civil Code, namely from chapters XII to XVIII and from articles 830 to 1130 . According to the law, there are two ways to obtain inheritance, namely;

1. As heirs according to the provisions of the Act;

2. Because it was appointed in a will.

"The first method is called inheriting "according to the provisions of the law" or 'ab intestato'. The second method is called inheritance by 'testamentair.'." 8

In western civil inheritance law, heirs are not only based on family class, but here it is regulated about the existence of a third party who is entitled to receive an inheritance from the heir where it is regulated by using a will / testament. The heirs $a b$ intestato referred to in the Subekti mentioned above are explained in the provisions in the Civil Code, which outlines the existence of groups of heirs known according to the Criminal Code 9 . "The first group includes children and their descendants in a straight line downwards, by not discriminating between male and female and by not distinguishing their birth order, excluding other family members in the upward and lateral line, although it may be between recent family members, ${ }^{10}$

Furthermore, "The right to inherit by the husband or wife of the deceased, only since 1935 (in the Netherlands in 1923) has been included in the law, namely they are equated with legal children. As a result of this new regulation, if there are no children at all, the husband or wife excludes other family members. This kind of incident has been strongly opposed by the sect which holds that it is sufficient for the husband or wife to be given the right to collect the proceeds from the inheritance.

In the event that the deceased has children from the first marriage and a second wife, the second wife in any way may not get a share exceeding the

${ }^{8}$ Subekti, (1985) Pokok Pokok Hukum Perdata, Jakarta : PT Intermasa, p.95

${ }^{9}$ A Chuasanga, Ong Argo Victoria. (2019). Legal Principles Under Criminal Law in Indonesia \& Thailand, Jurnal Daulat Hukum, Vol 2, No 1 (2019) http://jurnal.unissula.ac.id/index.php/RH/article/view/4218

${ }^{10} \mathrm{Ibid}$, p.99 
share of a child and at most only a quarter of the total inheritance, if the husband or second wife receives this inheritance, she must the price is taken into account and maybe he as an heir according to the law is no longer entitled to receive a share anymore, but even so, he still has the rights of an heir, for example together with other heirs the right to ask for the delivery of objects that are included in the inheritance. inheritance and participate in the distribution of the inheritance."11

\section{Research Methods}

The research method is a system and a process that absolutely must be carried out in a research and scientific development activity. Legal research is a scientific activity, which is based on certain methods, systematics and thoughts, which aims to study one or several certain legal phenomena, by analyzing them. Apart from that, an in-depth examination of the legal facts is also carried out, to then seek a solution to the problems that arise in the phenomenon in question.

As a scientific research, the series of research activities assessed from data collection to data analysis is carried out by taking into account the following scientific principles. This approach uses a secondary approach that is normative law or literature writing with a statutory approach, especially for reviewing laws and regulations related to the field of marriage law. Normative or secondary legal research includes:

a) Research on legal principles

b) Research on legal systematics

c) Research on vertical and horizontal synchronization

d) Legal comparison

e) Legal history.

Based on the description above, this approach method uses a normative juridical method which refers to the laws and regulations and is analyzed with the doctrine of legal scholars. Method Approach with normative juridical method is taken with the consideration that this approach is quite feasible to be applied, because in this method will be obtained comprehensive data and information that is normative both from primary, secondary and tertiary legal sources.

\section{Result and Discussion}

3.1. Inheritance Rights of Adopted Children Against the Assets of Adoptive Parents in Islamic Law, Civil Law, and Customary Law

${ }^{11}$ Ibid 
Indonesia adheres to a pluralistic legal system, which means that Indonesia adheres to more than one legal system. This also makes inheritance law divided into three legal systems, namely Western Law, Islamic Law, and Customary Law. In general, the notion of inheritance law is a legal rule that regulates the transfer of property rights, which is the overall rights and obligations of the person who inherits to his heirs and determines who is entitled to receive it.

There are three elements in inheritance law, namely the existence of an heir, the existence of inheritance and the existence of heirs. The definition of an heir is someone who has died and left something that can be transferred to his living family. ${ }^{12}$ The definition of inheritance is something left behind by a person who dies, either in the form of money or other material. Heirs are people who are entitled to receive the inheritance of the deceased, either because of family relations or marriage.

According to the law, those who are entitled to become heirs are blood relatives, both legal according to the law and outside of marriage, and the husband or wife who has lived the longest. If there is no blood family and the husband or wife who has lived the longest, then all the inheritance will become the property of the state, which is obliged to pay off the debts of the deceased person, as long as the price of the inheritance is sufficient for that. According to the law, there are two ways to get an inheritance, namely:

1) Inheritance according to law or also called inheritance $a b$ intestato is the law that regulates inheritance that occurs as determined by law. In this case if there is no will.

2) Inheritance due to a will is also called terstamentair inheritance (abtesto) is the inheritance law that regulates inheritance due to a will from the heir. There are many articles that regulate inheritance law in book II of the Civil Code, starting from Article 830 of the Civil Code to Article 1130 of the Civil Code. In the law of inheritance applies the principle, that only rights and. Only obligations in the field of property law can be inherited. Or rights and obligations that can be valued in money. So rights and obligations in the field of family law or personality, for example rights and obligations as husband or father, cannot be inherited. In addition, the principle also applies, that when a person dies, immediately all his rights and obligations pass to his heirs. This principle in French is called "le mort saisit le vif". ${ }^{13}$ This principle is in accordance with Article 830 of the Criminal Code. While the transfer of all rights and obligations of the heir by the heirs is called "saisine". ${ }^{14}$ There is also a principle called "hereditary petition" which is the right of the heir to demand all that is included in the inheritance of the heir against the person who controls the inheritance to be handed over to him based on his rights as heirs. This

\footnotetext{
${ }^{12}$ Amir Syariffudin, 2004, Hukum Kewarisan Islam, Kencana, Jakarta, p. 204

${ }^{13}$ Subekti, 2003, Pokok-Pokok Hukum Perdata, Intermasa, Jakarta, p. 95

14 Ibid
} 
principle is regulated in article $834 \mathrm{BW}$. In addition, there is also the principle of "de naaste in het bloed, erft het goed" which means that the blood is close, the inheritance is obtained. And to find out the closeness, a calculation must be made and for this, a degree measure is used with the X-1 formula. The greater the degree value, the more distant the family relationship with the heir. Vice versa, the smaller the value. The closer the blood relationship with the heir. For example: the measure of the degree of a biological child with the heir is 2-1 = 1 degree.

\section{A. Western Legal System (Civil)}

Inheritance law according to BW is the rule of law that regulates the transfer of ownership rights to his assets, constitutes the entire rights and obligations of the person who inherits to his heirs and determines who is entitled to receive it. Inheritance law can also be defined as a set of norms or rules that govern the law regarding wealth due to the death of a person, namely regarding this transfer for those who obtain it, both in the relationship between them and them and in the relationship between them and third parties. The elements of inheritance law in BW are:

1) Heir

2) An heir is a person who dies and leaves property. The person who replaces the heir in legal position regarding his wealth, either for the whole or for a comparable share, is called an heir or heir. The replacement of rights by them to the property in whole or for a comparable part, makes them people who acquire rights with general titles. ${ }^{15}$

3) The heirs according to the law and regulations in the BW have determined the families who are entitled to become heirs, as well as the portion of the distribution of their inheritance. The share of inheritance for children born out of wedlock is regulated as follows: ${ }^{16}$

4) $1 / 3$ of the share of legal children, if children born out of wedlock become joint heirs with legitimate children and the longest living widow or widower.

a) of the share of legitimate children, if children born out of wedlock become joint heirs with the second and third group heirs.

b) of the share of legitimate children, if children born out of wedlock become joint heirs of the fourth group of heirs, namely the heir's relatives up to the sixth degree.

\footnotetext{
${ }^{15}$ MR. A. Pitlo, 1990, Hukum Waris: Menurut Undang-Undang Hukum Perdata Belanda, Jakarta, p. 1

${ }^{16}$ Anisitus Amanat, 2000, Membagi Warisan Berdasarkan Pasal-Pasal Hukum Perdata BW, PT Raja Graffindo Persada, Jakarta, p.6
} 
c) of the share of legal children, if children born out of wedlock become joint heirs with the heir's grandparents, after cloving occurs. So in that case, the share of children born out of wedlock is not, because for the heirs of this fourth group, before the inheritance is divided, it must first be divided into two/kloving so that children born out of wedlock will get of the legal child's share of half the property inheritance from the father's line and of the legal child's inheritance from the mother's line so that it becomes part. However, if the heir does not leave an heir to the sixth degree, while there are only children born out of wedlock, the child out of wedlock gets the inheritance entirely or the property falls in the hands of children born out of wedlock, some of the heirs are one only one. It is different with children born from adultery and children born to parents who are not allowed to marry because both are very closely related, according to BW, they are not entitled to inherit property from their parents. In the provisions of the Civil Code, there are rules that stipulate people who are entitled to inherit property or what is referred to as absolute rights (legitieme portie). As regulated in Article 913 of the Civil Code which stipulates that the Legitime portie is a part of the inheritance that must be given to the heirs in a straight line according to the law, to which part of the deceased is not allowed to determine something, either as a gift between those who are still life.

In the provisions of the Civil Code, a person who is entitled to a legitimacy portie is called a legitimary. Those who are entitled to receive the inheritance are:

1) The first group, is the family in a straight line down which includes children and their descendants along with the husband or wife who is left behind or who has lived the longest.

2) The second group is the family in a straight line up which includes parents and siblings, both male and female and their descendants.

3) The third group includes grandparents, grandmothers and ancestors further upwards from the heirs.

4) The fourth group, includes family members in a lateral line and other relatives up to the sixth degree.

What is meant by his descendants are legitimate children born in marriage or recognized children outside of marriage. Adopted children can become part of the heirs if appointed in a will (testament). However, according to SEMA regulation No. 6/1983 Jus UU no. 23/1992 Jo. PP No. 54/2007 which is associated with the BW understanding of the position of children outside of marriage, then an adopted child is a child outside of marriage that is recognized by law. 
The logical consequence of this arrangement is that the child has a position as an heir as stipulated in Article 852 BW. Adoption of children in the 1917 Staatsblad implies equalizing the position of adopted children with biological children, both in maintenance and inheritance. The family relationship between an adopted child and his biological parents according to Article 12 of the Staatsblad of 1917 No.129 is to be broken.

As has been explained also in Articles 11, 12, 13 and 14 of the Staatsblad 1917 N0. 129 that an adopted child gets a clan descendant from his adoptive parents, an adopted child is considered born from the marriage of a husband and wife who adopts it, so that it is considered a legitimate child, the civil relationship between the adopted child and biological or biological parents is invalid. This implies that the Adopted Child has a position as a Legitimie Portie over all forms of Inheritance and as an absolute Heir.

So basically, inheritance is a legal act that arises because of a legal event, which in the rule of law is regulating. Therefore, the principle of Legitimie Portie must take precedence over the right to inherit, thus the provisions of Article $852 \mathrm{BW}$ are a form of the right to inherit the inheritance of an adopted child that has been legally recognized, even if it is not based on a written testament from a will.

\section{B. Islamic Legal System}

The Compilation of Islamic Law (KHI) defines adopted children in article 171 letter (h) as: "children who are in the care of their daily lives, education costs and so on, shifting their responsibilities from their original parents to their adoptive parents based on a court decision". Meanwhile, inheritance law is the law that regulates the transfer of ownership rights to the inheritance (tirkah) of the heirs, determining who is entitled to become heirs and how much of each ${ }^{17}$;

Adoption of a child, adoption, should be done with a court decision. By using the Court's decision, it can be used as authentic evidence of the adoption of a child. If in the future there is a dispute regarding the adoption of the child, the Court's decision can be used as evidence.

In the law of inheritance, adopted children do not include heirs, because biologically there is no familial relationship between the adopted child and his adoptive parents unless the adopted child is taken from the family of his adoptive parents. Because he is not an heir, the adopted child does not get a share as an heir from the inheritance of his adoptive parents. Even though they do not receive an inheritance from their adoptive parents, the adopted child receives a mandatory will to obtain the inheritance of his adoptive parents.

\footnotetext{
${ }^{17}$ Deen, Thaufiq., Ong Argo Victoria \& Sumain. (2018). Public Notary Services In Malaysia. JURNAL AKTA: Vol. 5, No. 4, 1017-1026. Retrieved from http://jurnal.unissula.ac.id/index.php/akta/article/view/4135
} 
This is as stated by the $\mathrm{KHI}$ in article 209 paragraph (a): "Appointed children who do not receive a will are given a mandatory will as much as $1 / 3$ of the inheritance of their adoptive parents", will not cause inheritance disputes. Because it is clear that the position of the adopted child is not the heir of the adoptive parents, the adopted child can receive the inheritance of his adoptive parents by way of a mandatory will.

An adopted child is not related by blood to his adoptive parents, but he has the right to get love like a biological child, to earn a living, to get a proper education and the right to fulfill the necessities of life. Due to the absence of blood relationship between the adopted child and his adoptive parents, the adopted child cannot become heir to the inheritance of his adoptive parents in accordance with article 174 of the Compilation of Islamic Law.

Even though the adopted child is not an heir, the adopted child is entitled to a share of the inheritance of his adoptive parents by getting a share on the basis of a mandatory will as stated in Article 209 paragraph (2) of the Compilation of Islamic Law, the amount of which is not more than (one third) of the entire inheritance of the person (adoptive parents). This normative juridical research method aims to determine the rights of adopted children to inheritance according to Islamic inheritance law in Indonesia. Often there are disputes between the heirs and adopted children regarding the distribution of the inheritance of the adoptive parents.

The settlement of Islamic inheritance disputes in which the parties are Muslim is resolved in the Religious Courts because in making decisions the Religious Courts refer to Islamic law and the Compilation of Islamic Law so that the decisions are in accordance with Islamic inheritance law. Meanwhile, the District Court resolves inheritance disputes based on the Civil Code and customary law so that they are not in accordance with the provisions of Islamic law.

\section{Customary Law System}

The Indonesian Customary Law System has various ethnic groups that differ in their customs and family systems which can generally be classified as follows:

1) Society with patrilineal system (patrilineal)

2) Society with a maternal system (matrilineal)

3) A society with a parental system A society with a parental system is a society whose kinship system draws lineage from both the father and the mother. Here we find a kinship unit based on family as a kin unit, for example the Javanese and those based on ethnicity such as the Dayak people in Kalimantan.

In this case the word family must be interpreted as a conjugal family (a family that emphasizes the importance of marital relations) and not a consanguin family (a family that emphasizes the importance of blood relations). ${ }^{18} \mathrm{~A}$ society with a

18J.B.A.F, Mayor Polak, 1976, Sosiologi Suatu Buku Pengantar Ringkas, Ichtiar Baru, Jakarta, p. 346 
matrilineal system is a society whose kinship system draws lineage from the female or maternal side.

In this case, it is not the child or female offspring that is important, nor is the father's relatives important for a child, but what is important for a child is the child or female offspring and the mother's family or relatives.

The people who follow this system are the Minangkabau, Kerinci, and Semendo people. A society with a patrilineal system is a society whose kinship system draws lineage from the male or father side. In a society like this, for a child, the father's kinship group becomes important, both in terms of inheritance, social relations, and marriage. The people who adhere to this kinship system are the people of Tapanuli, Lampung, Ambon, and Bali.

The inheritance of adopted children in the customary law system is very dependent on the habits that exist in the community. For example, according to the customary law of Central Java, an adopted child is not entitled to inherit the property of his adoptive parents which is not of such status in accordance with Supreme Court Decision No. 384/Sip/1961 dated July 4, 1961.

If the adoptive parents are afraid that the adopted child will not get a fair share or may be completely excluded by the biological child using the basis of Islamic law, then it is the habit of the adoptive parent to give a share of the inheritance to the adopted child before he dies with a grant or will. After all, the adopted child has the right to inherit from his adoptive parents, but he must not exceed the biological child. Meanwhile, according to West Java customary law, the adopted child has the same position as the biological child so that he is entitled to inherit property like his biological child in accordance with the Bandung High Court Decision No. 317/1971/C/Bdg dated August 3, 1972.

In Islamic law, adoption is contained in the compilation of Islamic law which emphasizes adopted children as children who are in the care for daily living, expenses, education and so on, shifting their responsibilities from their original parents to their adoptive parents based on court decisions. Thus, according to Islamic law, what is allowed is the adoption of a child in the form of a relationship such as child rearing. ${ }^{19}$

Such adoption is in accordance with the rules in Al-Azhab verses 4 and 5, where adoption according to Islamic law does not give the adopted child a status like the biological child of the adopting parents, so that the adopted child still has a blood relationship with the parents (his biological). As for the way adopted children in Islamic law to get inheritance from their adoptive parents is through a will or it can also be through a grant.

In Balinese customary law, the definition of an adopted child is another person's child who was adopted by his adoptive parents according to local customary rules, so that he has the same position as a biological child born to his adoptive

${ }^{19}$ Fuad Mohd. Fachruddin, 1985, Masalah Anak Dalam Hukum Islam, Pedoman Ilmu Jaya, Jakarta, p. 81. 
parents. Adoption of children in Balinese customary law brings legal consequences in family relations, inheritance and society.

The consequence is that all the rights and obligations of the adoptive parents will be continued by the adopted child himself, as befits a biological child. In Balinese customary law, adopted children are sought to come from the closest family environment, the purusa line, which is the pasidi work.

There are three groups of pasidikarya, namely pasidikarya waris (having a mutual inheritance relationship), pasidikarya sumbah (having a relationship with each other to worship ancestors), and pasidikarya idih pakidih (having a marital relationship). If there is no line from the purusa line, it can be sought from the family according to the pradana line (mother line).

If it is not found, it can be attempted from another family in one soroh and finally there is none at all, then the adoption can be carried out even though there is no family relationship (sekama-kama). Adopted children must be Hindu. If someone is appointed who is not a Hindu, the adoption of the child will be rejected by the villagers because the purpose of adopting a child is, among others, to continue the inheritance in the form of obligations and rights, including various obligations of traditional villages, especially in relation to sacred places (temples).

\subsection{How to Knowing and Understanding the Implementation of the Distribution of Inheritance to Adopted Children}

To get a clearer understanding of this situation, the author will discuss this by following the legal system in force in Indonesia: the inheritance law system according to the Civil Code, the inheritance law system according to Islamic law, the inheritance law system according to customary law. The inheritance or descent system adopted by BW is a limited parental and bilateral system, where each family member relates himself to the descendants of his father and mother. ${ }^{20}$

Because the relationship between inheritance law is very close to family law, then in discussing inheritance this is a discussion that includes marriage law. In the BW Inheritance Law system, "for an inheritance the provisions regarding inheritance based on the law are applied unless the testator takes other provisions in a will," 21 Furthermore, regarding assets or inheritance, it is regulated in Article 849 BW, which states that: The law does not consider the nature or origin of the goods in an inheritance to regulate the inheritance of them. ${ }^{22}$

In the Civil Code, the term Legitieme Portie is used because inheritance only exists, when the erflater has died, then there is a transfer of ownership rights to Erfgenaam. Then regarding how and who is entitled to the inheritance of the

20 Risko El Windo Al Jufri, Tesis, Kedudukan Anak Angkat Dalam Hukum Waris Adat Pada Masyarakat Warga Negara Indonesia Keturunan Tionghoa di Kota Jambi, Universitas di Ponegoro, dimuat dalam sumber http://rangga263.wordpress.com/2011/08/28/hak-warisanakangkat-tanpa-surat-wasiat/, 30, 2021.

${ }^{21}$ Satrio, Op Cit, p. 17

${ }^{22}$ Civil Code, Op Cit, Article 849 
erflater, BW has arranged it in two (2) forms, namely by descent ab intenstato and based on testamenteir erfrecht. Meanwhile, regarding the subject who is entitled to inheritance, BW determines three parties: Erfgenaam, the State and Third Parties. Based on this understanding, there are conditions for the transfer of the assets of the heir to his heirs including general conditions and absolute conditions. The general conditions are:

a) There are people who have died (Article 830 of the Civil Code);

b) the heirs left behind (Article 836 of the Civil Code);

c) Regarding the payment of debts (Article 1100 of the Civil Code).

While the absolute requirement is that someone must die (Article 830 of the Civil Code), unless it can occur in an absence (Article 467 in conjunction with Article 470 of the Civil Code) that the testator has not died. Conditions for death or there must be someone who dies, in addition to the general conditions, is also an absolute requirement. ${ }^{23}$ Regarding inheritance, it is not the case with $\mathrm{KHI}$ and Law no. 1 of 1974 concerning marriage which divides 2 (two) family assets, namely original assets and gono-gini assets, then the inheritance system according to the Civil Code does not separate original assets and gono-gini assets in inheritance as a provision of Article 849 of the Civil Code which states " the law does not consider the nature or origin of the goods from an inheritance to regulate the inheritance of them." 24

This means that either the innate property or the gono-gini property becomes an inheritance. Basically the inheritance system adopted by the Civil Code is a limited Parental or Bilateral system, where each family member connects himself to the descendants of his father and mother. However, in addition to hereditary inheritance or an $a b$ intensato inheritance system according to the law without a will as stipulated in Article 832 of the Civil Code, there is also an inheritance system according to a will (testament) as a provision of Article 875 of the Civil Code which states that a will or testament is a deed containing a person's statement about what he wants, happens after he dies and can be revoked by him. ${ }^{25}$

How to inherit heirs in the Civil Code system is divided into 2 (two) kinds, namely: ${ }^{26}$

a. Heirs according to the Law (Ab Intenstato) the heirs according to the Law $a b$ Intenstato are heirs who have blood relations with the heir. The heirs based

\footnotetext{
${ }^{23}$ Djaja S. Meliala, Op Cit, p. 198

${ }^{24} \mathrm{Ibid}$

${ }^{25}$ Djaja S. Meliala, Op Cit, p. 224

${ }^{26}$ https://fh.unram.ac.id./wp-content/kedudukan-anakangkat-menurut-KUHP-dan-KHI, accessed on 30 June 2021
} 
on this law based on their position are divided into two parts, namely:

1) Heirs based on their own position (Uit Eigen Hoofde). The heirs belonging to this group are those who are called to receive inheritance based on their own position in Article 85 paragraph (2) of the Civil Code it is stated: "they inherit head by head if by death they have a relationship with one another and each has rights with himself."

2) Based on Replacement (Bij Plaatvervuling). Heirs who receive heirs by substituting, namely heirs who receive inheritance as a substitute for heirs who are entitled to receive inheritance who died first from the testator. The heirs of Bij Plaatvervuling are regulated in Articles 841-848 of the Civil Code.

b. Heirs based on a will (testament) The heirs here are people who are appointed or appointed by the testator with a will as his heir (erfstelling), who are then referred to as ad testamento heirs. A will or testament in the Civil Code is a person's statement about what he wants after he dies. In principle, a final statement of will is out of one party only and can be withdrawn at any time by the testator expressly or secretly. The Testament rules contained in Article 874 of the Civil Code contain a condition that the testament must not conflict with the Legitime Portie in Article 913 of the Civil Code and the most common is a testament containing what is called erfstelling, namely the appointment of a person or several persons to be heirs who will inherit all or part of the inheritance. Substitute heirs can be divided into three groups, namely: ${ }^{27}$

1) Substitution in a straight line down;

2) Replacement in a straight line sideways;

3) Substitution in the line to the side deviates;

The provisions of Article 852 of the Civil Code is a form of the right to inherit the inheritance of an adopted child that has been legally recognized even though it is not based on a written testament. Meanwhile, the right to inherit an adopted child who is legally adopted according to the law on the property of his biological parents must be reviewed according to Stb. No. 129 of 1917 and according to Law No. 23 of $2002 .^{28}$

Basically the inheritance system or determination of who has the position as heir is based on descent or blood relation or ab intestato and by will or testament refers to who is the heir who has absolute rights or legitieme portie or part of the inheritance to be inherited given to the heirs either in a straight line up or

27 Ibid.

28 Ibid. 
down. ${ }^{29}$ Therefore, an adopted child is not related by blood to his adoptive parents.

\section{Closing}

Indonesia adheres to several systems of inheritance law including the civil law system, Islamic law and customary law. In civil law, adopted children still get inheritance rights from their adoptive parents. The form of the right to inherit the inheritance of an adopted child that has been legally recognized, even if it is not based on a written testament from a will. While Islamic law, even though the adoption of the child is carried out in accordance with the applicable provisions, it will still not cause an inheritance dispute, because it is clear that the position of the adopted child is not the heir of the adoptive parents, the adopted child can receive the inheritance of his adoptive parents by way of a mandatory will. Then in customary law, the inheritance system used is dependent on the custom where the adopted child lives. Amount The inheritance law system that applies in Indonesia is of course only one system that can be implemented for heirs to be able to distribute inheritance. This implementation depends on the agreement of all heirs. The importance of implementing the inheritance law system is of course to guarantee the rights of each heir, including adopted children who have been adopted.

\section{References}

Journals:

[1] A Chuasanga, Ong Argo Victoria. (2019). Legal Principles Under Criminal Law in Indonesia \& Thailand, Jurnal Daulat Hukum, Vol 2, No 1 (2019) http://jurnal.unissula.ac.id/index.php/RH/article/view/4218

[2] Deen, Thaufiq., Ong Argo Victoria \& Sumain. (2018). Public Notary Services In Malaysia. JURNAL AKTA: Vol. 5, No. 4, 1017-1026. Retrieved from http://jurnal.unissula.ac.id/index.php/akta/article/view/4135

Books:

[1] Ahmad bin Syuaibi Abu, Abdu al Rahman al-Nasaaiy, Sunan Al-Nasaaiy, (Halab : Maktabu al-Mathbuu"aati al-Islamiati, 1986), juz 6, hadits no. 3481

[2] Ahmad Kamil, Fauzan. 2008. Hukum Perlindungan \& Pengangkatan Anak di Indonesia. Jakarta : PT. Raja Grafindo Persada

[3] Andi Syamsu Alam \& M. Fauzan, Hukum Pengangkatan Anak Perspektif

${ }^{29}$ https://dspce.library.uph/1849/1/13-01-2013/HakMewaris-Anak-Angkat-terhadap-Orang-TuaAngkat, accessed on 30 June 2021. 
Islam (Jakarta: Kencana, 2008), p. 20, cited from Wahbah Zuhaily, Fiqh Islamy Wa Adillatuh

[4] Beni Ahmad Saebani, Fiqih Mawaris, (Bandung : Pustaka setia, 2012)

[5] D.Y. Witanto, Hak \& Kedudukan Anak Luar Kawin, Kencana, Jakarta: 2012

[6] Darwan Prinst, Hukum Anak Indonesia. (Bandung : PT. Citra Aditya Bakti, 1997)

[7] Departemen Pendidikan \& Kebudayaan, Kamus Besar Bahasa Indonesia. Balai Pustaka: Jakarta, 2010

[8] Effendi Perangin, Hukum Waris, (Jakarta: Rajawali Pers, 2008)

[9] Eman Suparman, Hukum Waris Indonesia dalam perspektif islam, adat, \& BW.(Bandung: Refika Aditama 2005)

[10] Hilman Hadikusuma, Hukum Perkawinan Indonesia Menurut Perundangan, Hukum Adat, Hukum Agama (Bandung:Mandar Maju, 2007)

[11] Kamus Nasional Indonesia, Jilid IA, (Jakarta: PT.Cipta Adi Pusaka, 1988)

[12] M. Buddiarto, S.H, Pengangkatan Anak Ditinjau Dari Segi Hukum, AKAPRESS, 1991

[13] Mochtar Kusumaatmadja, Hukum, Masyarakat \& Pembinaan Hukum Nasional ( Bandung: Binacipta. 1976)

[14] Muhammad bin Yaziid Abu, Abdillah al Quzwainiy, Sunnan Ibn Majah, (Beirut : Daral Fikr, t.t), juz 8, hadits no. 2708

[15] Munawwir,ahmad warson. Kamus Al Munawwir (Pustaka Progressif, Surabaya, thun1997)

[16] Musthofa Sy, Pengangkatan Anak, (Jakarta: Kencana, 2008), print.- 2 .

[17] Nurul Irfan, Nasab \& Status Anak Dalam Hukum Islam. (Jakarta : Amzah, 2012)

[18] Nurul Irfan, Nasab \& Status Anak Dalam Hukum Islam. (Jakarta : Amzah, 2012) 
[19] Simorangkir, JCT. Kamus Hukum, (Jakarta: Aksara Baru, 1987), print.- 1

[20] Soerjono Soekanto, Hukum Adat Indonesia (Jakarta:Rajawali Pers, 2010)

[21] Subekti, Pokok Pokok Hukum Perdata, ( Jakarta:PT Intermasa, 1985)

[22] Syamsu Alam, dkk, Hukum Pengangkatan anak perspektif islam, (Jakarta: Kencana, 2008), print.-1

[23] Tim penyusun Kamus Pusat Bahasa, Kamus Besar Bahasa Indonesia. ed.3 ( Jakarta: Balai Pustaka 2001)

Internet:

Kamus Besar, (Online), (https://www.kamusbesar.com/anak-asuh, accessed on 01 July 2021) 